\title{
Penerapan Model Discovery Learning Untuk Meningkatkan Pembelajaran IPA Materi Gaya pada Kelas IVA SD N Dukuhan Kerten Surakarta tahun ajaran 2020/2021
}

\section{Isni Ramadhantri}

Universitas Sebelas Maret

isniramadhantri01@gmail.com

Article History

received 30/4/2021

\begin{abstract}
Based on observation at SD N Dukuhan Kerten Surakarta: it shows the condition that students are passive in learning, learning method commonly used in online learning is assignment method, learning model commonly used in Science learning outcame of fourth A grade students are low based on-reaction test. This research aims to improve the learning of the force material in fourth A grade at SD N Dukuhan Kerten Surakarta for 2020/2021. This research is a classroom action research (CAR) conducted in two cycles, each cycle consisting of two meetings. The results showed that the average results of student observation in the first cycle was $82.63 \%$ and the second cycle was $87.93 \%$. While the average learning outcomes of students in the first cycle is $81.23 \%$ and the second cycle is $89.59 \%$. Based on the results of the research, it can be said that application model of the discovery learning can improve science learning of the force material in class IVA at SD N Dukuhan Kerten Surakarta in the 2020/2021 academic year.
\end{abstract}

Keywords: Discovery Learning, Science, Force

\begin{abstract}
Abstrak
Berdasarkan observasi di SD N Dukuhan Kerten Surakarta menunjukkan kondisi yakni : peserta didik pasif dalam pembelajaran, metode pembelajaran yang biasa digunakan dalam pembelajaran IPA selama pembelajaran daring adalah metode penugasan, model pembelajaran yang biasa digunakan dalam pembelajaran ipa selama pembelajaran daring belum melibatkan peserta didik melakukan penemuan secara mandiri/ kelompok, hasil belajar IPA siswa kelas IVA tergolong rendah berdasarkan tes pratindakan. Penelitian ini bertujuan untuk meningkatkan pembelajaran materi gaya pada kelas IVA SD N Dukuhan Kerten Surakarta tahun ajaran 2020/2021 melalui model discovery learning. Penelitian ini merupakan penetitian tindakan kelas (PTK) yang dilaksanakan sebanyak dua siklus setiap siklus terdiri dari dua pertemuan. Hasil penelitian menunjukkan bahwa rata-rata observasi siswa pada siklus ! sebesar $82.63 \%$ dan siklus II sebesar $87.93 \%$. Sedangkan rata-rata hasil belajar pada siklus I sebesar $81.23 \%$ dan siklus II sebesar $89.59 \%$. Berdasarkan hasil penelitian dapat disimpulkan bahwa penerapan model discovery learning dapat meningkatkan pembelajaran IPA materi gaya pada kelas IVA SD N Dukuhan Kerten Surakarta tahun ajaran 2020/2021.
\end{abstract}

Kata kunci: Discovery Learning, IPA, Gaya 


\section{PENDAHULUAN}

Semenjak Indonesia darurat pandemi COVID-19 pemerintah mengeluarkan berbagai kebijakan untuk mengurangi angka penyebaran virus COVID-19. Dibidang pendidikan, Kementerian Pendidikan dan Kebudayaan (Kemendikbud) menerbitkan Surat Edaran Nomor 4 tahun 2020 tentang Pelaksanaan Pendidikan Dalam Masa Darurat Coronavirus Disease (COVID-19) yang diperkuat dengan Surat Edaran Nomor 15 tahun 2020 tentang Pedoman Penyelenggaraan Belajar dari Rumah dalam Masa Darurat Coronavirus Disease (COVID-19). Berdasarkan surat edaran tersebut pelaksanaan kegiatan pembelajaran dilaksanakan secara daring yang menuntut berbagai pihak yang terlibat dapat menguasai teknologi dengan baik. Dalam upaya menciptakan generasi yang berkualitas dan berkarakter maka diperlukan pendidikan dan kurikulum yang sesuai. Pada masa sekarang ini pendidikan jenjang sekolah dasar dan menengah telah menggunakan kurikulum 2013 dengan mengintegrasikan pendidikan abad 21.

Pendidikan abad 21 merupakan pendidikan yang mengintegrasikan antara pengetahuan, keterampilan, dan sikap, serta penguasaan terhadap TIK (Ariyana, 2018: 14). Pada abad ini perkembangan teknologi informasi berkembang sangat pesat sehingga dibutuhkan sumber daya manusia yang berkualitas. Cara untuk menghasilkan peserta didik berkualitas yang memiliki kompetensi utuh dikenal dengan kompetensi abad 21. Menurut Kemendikbud (2017: 5) Kompetensi Abad 21 yang harus dimiliki peserta didik dikenal dengan istilah $4 C$ (critical thinking, communication, collaboration, and creativity).

IPA merupakan salah satu wahana yang dianggap paling tepat untuk menanamkan pengetahuan, sikap, dan keterampilan pada peserta didik melalui proses pembelajaran. IImu Pengetahuan Alam (IPA) atau sains merupakan ilmu pengetahuan yang mempelajari tentang seluruh alam semesta beserta isinya dan termasuk semua peristiwa-peristiwa yang terjadi di dalamnya, baik itu berupa fakta-fakta, konsepkonsep maupun prinsip-prinsip yang semuanya terorganisir dan sistematis sehingga menjadi suatu proses untuk memproduksi pengetahuan.

Data yang diperoleh dari guru kelas IVA SD N Dukuhan Kerten Surakarta masih tergolong rendah, dimana hasil belajar IPA kelas IVA SD N Dukuhan Kerten Surakarta pada Penilaian Harian (PH) Tema 7 tahun ajaran 2020/2021 terdapat 10 atau $41.67 \%$ peserta didik yang hasilnya kurang dari KKM (Kriteria Ketuntasan Minimal) dan hanya 14 atau $58.33 \%$ peserta didik yang sudah mencapai batas ketuntasan belajar. Nilai KKM yang ditentukan sekolah untuk muatan IPA adalah 75.

Berdasarkan observasi dan wawancara pada wali kelas IVA SD N Dukuhan Kerten Surakarta, diperoleh informasi bahwa: (1) peserta didik pasif dalam pembelajaran, misalnya peserta didik belum berani bertanya dan sulit mengemukakan pendapat ketika pembelajaran berlangsung, (2) metode pembelajaran yang biasa digunakan dalam pembelajaran IPA selama pembelajaran daring adalah metode penugasan, (3) model pembelajaran yang biasa digunakan dalam pembelajaran IPA selama pembelajaran daring belum melibatkan peserta didik melakukan penemuan secara mandiri/ kelompok (4) hasil belajar IPA siswa kelas IVA tergolong rendah.

Dari permasalahan yang ditemukan saat observasi menunjukan aktivitas dan hasil belajar peserta didik masih rendah. Hal tersebut menandakan bahwa adanya permasalahan yang perlu dicari solusi untuk memecahakan permasalahan tersebut. Mengingat guru mempunyai peranan besar dalam proses pembelajaran, maka guru diharuskan untuk selalu proaktif dan responsif terhadap hal-hal yang terjadi di dalam kelas maupun di lingkungan peserta didik. Perlu adanya inovasi terhadap model yang digunakan saat pembelajaran untuk meningkatkan aktivitas peserta didik sehingga dapat meningkatkan hasil belajar peserta didik.

Berdasarkan permasalahan yang telah dipaparkan di atas, peneliti menetapkan untuk menggunakan model pembelajaran Discovery learning. Discovery learning 
merupakan suatu model pemecahan masalah yang akan bermanfaat bagi peserta didik dalam menghadapi kehidupannya di kemudian hari. Penerapan model discovery learning ini bertujuan supaya peserta didik mampu memahami materi gaya dengan sebaik mungkin dan pembelajaran lebih terasa bermakna, sehingga hasil belajar siswa pun akan meningkat. Karena model discovery learning ini dalam prosesnya menggunakan kegiatan dan pengalaman langsung sehingga akan lebih menarik perhatian anak didik dan memungkinkan pembentukan konsep-konsep abstrak yang mempunyai makna, serta kegiatannya pun lebih realistis (Rosarina dkk, 2016).Menurut Hosnan (2014: 289-291) Langkah-langkah menerapkan model pembelajaran discovery learning yaitu (1) Stimulation (stimulasi/pemberian rangsangan), (2) Problem statement (pernyataan/ identifikasi masalah), (3) Data collection (pengumpulan data), (4) Data processing (pengolahan data), (4) Verification (pembuktian) dan (5) Generalization (menarik kesimpulan/ generalisasi).

Adapun penelitian Sispariyanto, Stefanus dan Agustina (2019) dengan penelitian berjudul "Upaya Meningkatkan Keaktigan dan Hasil Belajar IPA Melalui Model Discovery Learning di Kelas IV SD" yang menunjukan bahwa model pembelajaran Discovery LEarning dapat meningkatkan pembeajaran IPA siswa.

Berdasarkan uraian di atas, maka peneliti berkeinginan untuk melakukan penelitian tindakan kelas dengan judul "Penerapan Model Discovery Learning Untuk Meningkatkan Pembelajaran IPA Materi Gaya pada Kelas IVA SD N Dukuhan Kerten Surakarta tahun ajaran 2020/2021.

\section{METODE}

Penelitian ini merupakan penetitian tindakan kelas (PTK) kolaboratif antara peneliti dengan guru kelas IVA SD N Dukuhan Kerten tahun ajaran 2020/2021. Penelitian dilaksanakan selama dua siklus dengan dua pertemuan untuk setiap siklus. Subjek dalam ini penelitian adalah guru dan peserta didik kelas IV dengan jumlah 24 peserta didik terdiri dari 13 peserta didik laki-laki dan 11 peserta didik perempuan.

Data yang digunakan berupa data kualitatif yakni informasi penerapan model discovery learning dapat meningkatkan pembelajaran IPA materi gaya tema 8 pada kelas IVA SD N Dukuhan Kerten tahun ajaran 2020/2021. Data kuantitatif yang digunakan berupa nilai hasil belajar peserta didik kelas IVA SD N Dukuhan Kerten. Sumber data yang digunakan dalam penelitian ini yaitu guru, peserta didik, dan dokuman. Uji validitas data dalam penelitian ini mengunakan teknik triangulasi.Teknik analisis data terdiri dari reduksi data, penyajian data, dan menarik kesimpulan (Sugiyono, 2017: 246).

Indikator kinerja penelitian dala penetian ini adalah peningkatan pembelajaran IPA materi gaya tema 8 dengan ketercapaian $85 \%$. Penelitian ini menggunakan prosedur penelitian yang terdiri dari perencanaan, pelaksanaan, pengamatan, dan refleksi (Arikunto, 2013: 137).

\section{HASIL DAN PEMBAHASAN}

Penerapan model pembelajaran discovery learning untuk meningkatkan pembelajaran siswa kelas IV SD N Dukuhan Kerten dilakukan sebanyak dua siklus setiap siklus terdiri dari dua pertemuan. Tiap pertemuan menerapkan enam langkah model pembelajaran Discovery Learning yaitu: (1) stimulation, (2) problem statement, (3) data collection, (4) data processing, (5) verification, (6) generalization. Langkahlangkah model pembelajaran discovery learning mengacu pada Hosnan (2014: 289291), Ahmadi dan Prasetya (Illahi, 2012: 87-88) dan Wahjudi (2015: 2-3) yang kemudian disimpulkan menjadi langkah yang sudah disebutkan di atas.

Hasil observasi penerapan model pembelajaran Discovery Learning terhadap guru dan siswa mengalami peningkatan pada setiap siklusnya hingga mencapai indikator kinerja penelitian yang ditargetkan yaitu $85 \%$. 
Tabel 1. Persentase Hasil Observasi Guru dan Siswa

\begin{tabular}{cccc}
\hline & & \multicolumn{2}{c}{ Siklus } \\
& & I & II \\
\hline Guru & Persentase (\%) & 83.50 & 87.93 \\
Siswa & Persentase (\%) & 82.63 & 87.93 \\
\hline
\end{tabular}

Berdasarkan tabel diatas, observasi terhadap guru pada siklus I persentase hasil $83.50 \%$ dan pada siklus II menjadi $87.93 \%$. Antara siklus I dan II meningkat 4,43\%. Observasi terhadap siswa pada siklus I persentase mencapai $82.63 \%$ dan pada siklus II menjadi $87.93 \%$. Antara siklus I dan II meningkat 5,30\%. Dapat disimpulkan bahwa setiap siklus mengalami peningkatan, berarti langkah Discovery Learning setiap siklus semakin meningkat.

Tabel 2. Hasil Belajar Siswa Siklus I dan II

\begin{tabular}{lcc}
\hline & Siklus I (\%) & Siklus II (\%) \\
\hline Tuntas & 81.23 & 89,59 \\
Belum Tuntas & 18.75 & 10,41 \\
\hline
\end{tabular}

Berdasarkan tabel diatas, dapat disimpulkan bahwa persentase ketuntasan siswa juga meningkat dari $81.23 \%$ di siklus I dan menjadi $89,59 \%$ di siklus II. Hasil observasi dan wawancara, guru berhasil menerapkan langkah langkah model pembelajaran Discovery Learning dan siswa mengikuti pembelajaran dengan baik.

Dengan demikian penerapan model pembelajaran Discovery Learning dapat meningkatkan pembelajaran IPA dilihat dari persentase peserta didik yang memenuhi ketercapaian target dari siklus I-II. Hasil penelitian ini memperkuat penelitian yang dilakukan Rahmat Budiono (2018) yang menyatakan bahwa penerapan model Discovery Learning dapat meningkatkan pembelajaran dilihat perilaku siswa berdasarkan tingkat pencapaian indikator pembelajaran yang mencakup penilaian proses dan hasil.

Kendala dalam penelitian ini ada 5 yaitu (1) guru kurang memberikan pernyataan pemantik kepada siswa untuk memancing siswa bertanya; (2) siswa belum percaya diri dan kurang termotivasi untuk mengajukan pertanyaan; (3) beberapa peserta didik belum melakukan percobaan dengan baik; (4) peserta didik kurang aktif dalam memberikan tanggapan hasil percobaan di WAG karena peserta didik malu ketika akan menanggapi dan kurangnya interaksi guru dengan peserta didik; (5) guru belum menunjuk semua peserta didik untuk melakukan persentasi atau menanggapi.

Kendala wajar ditemui karena siswa belum terbiasa menggunakan model pembelajaran discovery learning. Adapun solusi yang diberikan peneliti adalah (1) guru lebih banyak memberikan pernyataan pemantik kepada siswa dengan bahasa yang mudah dipahami; (2) guru memberikan dorongan dan motivasi kepada siswa untuk bertanya dengan percaya diri; (3) guru memberikan motivasi kepada siswa dan membuat video percobaan sehingga peserta didik bisa meniru atau mengamati; (4) Guru memberi motivasi dan penghargan pada peserta didik yang memberi tanggapan atau aktif di WAG; (5) guru mencatat peserta didik yang sudah aktif dan menunjuk peserta didik yang belum berperan aktif dalm persentasi maupun menanggapi teman yang sedang persentasi.

\section{SIMPULAN}

Pembelajaran materi gaya tema 8 Daerah Tempat Tinggalku pada peserta didik kelas IVA SD N Dukuhan Kerten Surakarta tahun ajaran 2020/2021 dilaksanakan 
sesuai dengan langkah model discovery learning yakni Stimulation, Problem statement, Data collection, Data processing, Verification dan Generalization. Pembelajaran dengan menggunakan model discovery learning dilakukan oleh guru untuk mengatasi permasalahan yang ditemukan yaitu: (1) Peserta didik pasif dalam pembelajaran (2) Metode pembelajaran yang biasa digunakan dalam pembelajaran IPA selama pembelajaran daring adalah metode penugasan. (3) Model pembelajaran yang biasa digunakan dalam pembelajaran IPA selama pembelajaran daring belum melibatkan peserta didik melakukan penemuan secara mandiri/ kelompok. (4) Hasil belajar IPA siswa kelas IVA tergolong rendah. Berdasarkan data yang diperoleh peneliti yang tersaji dalam tabel tersebut, dapat diketahui bahwa pembelajaran materi gaya tema 8 Daerah Tempat Tinggalku pada peserta didik kelas IVA SD N Dukuhan Kerten Surakarta tahun ajaran 2020/2021 dapat meningkat melalui model discovery learning yang dapat diketahui berdasarkan persentase peserta didik memenuhi indikator kinerja penelitian dari pratindakan, siklus I, dan siklus II. Penerapan model pembelajaran Discovery Learning dapat meningkatkan pembelajaran peserta didik muatan pelajaran IPA Kelas IVA SD Negeri Dukuhan Kerten Surakarta tahun ajaran 2020/2021, dibuktikan dengan peningkatan persentase siswa yang memenuhi ketercapaian target sebesar $85 \%$.

\section{DAFTAR PUSTAKA}

Arikunto, S. (2013). Prosedur Penelitian Suatu Pendekatan Praktik. Jakarta: Bumi Aksara.

Ariyana, Yoki., dkk. (2008). Buku Pegangan Pembelajaran Berorientasi pada Keterampilan Berpikir Tingkat Tinggi. Jakarta: Kemendikbud. Arikunto, S. (2010). Prosedur Penelitian Suatu Pendekatan Praktik. Jakarta: Rineka Cipta

Budiono, R. (2018). Penerapan Model Discovery Learning dengan Media Konkret untuk Meningkatkan Pembelajaran Matematika tentang Bangun Datar Pada Siswa Kelas V SD Negeri 6 Panjer Tahun Ajaran 2017/2018. Skripsi Tidak Diplublikasikan. Universitas Sebelas Maret, Surakarta

Hosnan, M. (2014). Pendekatan Saintifik dan Kontekstual dalam Pembelajaran Abad 21. Bogor: Ghalia Indonesia

Illahi, M. (2012). Pembelajaran Discovery Strategy \& Mental Vocational Skill. Yogyakarta: DIVA Press.

Kemendikbud. (2017). Panduan Implementasi Kecakapan Abad 21 Kurikulum 2013 di Sekolah Menengah Atas. Jakarta: Direktorat Pembinaan Sekolah Menengah Atas.

Rosarina, G,. Ali Sudin., Atep Sujana. (2016). Penerapan Model Discovery Learning Untuk Meningkatkan Hasil Belajar Siswa Pada Materi Perubahan Wujud Benda. Jurnal Pena Ilmiah. Vol 1 (1).

Sispariyanto,E., Stefanus, C., Tyas, A. (2019). Upaya Meningkatkan Keaktigan dan Hasil Belajar IPA Melalui Model Discovery Learning di Kelas IV SD. Majalengka. Jurnal Cakrawala. 5 (2). https://jurnal.unma.ac.id/index.php/CP/

Sugiyono. (2017). Metode Penelitian Kuantitatif, Kualitatif, dan R\&D. Bandung: Alfabeta.

Wahjudi, E. (2015). Penerapan Discovery Learning Dalam Pembelajaran IPA Sebagai Upaya untuk Meningkatkan Hasil Belajar Siswa Kelas IX-I di SMP Negeri 1 Kalianget. Jurnal Lensa, 5 (1), 2-3. 